\title{
Evaluation of water quality in fee-fishing ponds located in Guarapiranga's sub basin, Upper Tietê River basin, São Paulo State
}

\author{
A. S. Bueno ${ }^{a *}$ (D), E. S. Rodrigues ${ }^{b}$ (D), L. S. Maruyama (D) $^{\text {and P. M. G. Castro }}$ (iD \\ aPrograma de Pós-graduação, Instituto de Pesca, Av. Francisco Matarazzo, 455, Parque da Água Branca, Perdizes, \\ São Paulo, SP, CEP 05001-900, Brasil

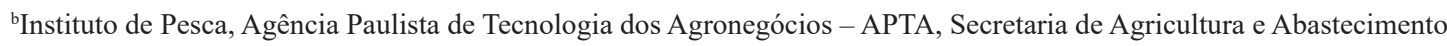 \\ - SAA, Av. Bartolomeu de Gusmão, 192, Ponta da Praia, Santos, SP, CEP 11030-906, Brasil \\ ${ }^{c}$ Centro de Pesquisa e Desenvolvimento de Recursos Hídricos - CPDRH, Instituto de Pesca, Agência Paulista de \\ Tecnologia dos Agronegócios - APTA, Secretaria de Agricultura e Abastecimento - SAA, Av. Francisco Matarazzo, 455, \\ Parque da Água Branca, Perdizes, São Paulo, SP, 05001-900, Brasil \\ *e-mail: buenoalex0@gmail.com
}

Received: June 18, 2018 - Accepted: January 16, 2019 - Distributed: May 31, 2020

(With 07 figures)

\begin{abstract}
This study intended to characterize the fee-fishing ponds located in Guarapiranga's sub-basin both in terms of structure and environmental conditions. The studied region was mapped and 15 out of 24 georeferenced fee-fishing ponds had their owners interviewed through semi-structured questionnaires. In addition to that, samples were collected from the seven fee-fishing ponds closest to the reservoir throughout a seasonal cycle divided in four sample collections carried out between November 2013 and August 2014, aiming at measuring the following variables in situ: water flow rates, $\mathrm{pH}$, turbidity, electrical conductivity and dissolved oxygen concentration in affluents and effluents. Other samples were taken in order to assess total phosphorus (TP) and total nitrogen (TN) concentrations. Our results show a decrease in dissolved oxygen concentration along with an increase in TP and TN concentration in effluents, as compared to affluents. TP e TN concentrations exceeded the permitted values established by CONAMA 357/2005 - Class II resolution in all effluents at least during part of the year. High nutrient levels were observed in affluents, condition with which basins that have been affected by population growth are commonly met. It was verified, by interviewing the owners regarding venture management and by analyzing the collected samples, that there is significant correlation between the daily feeding and the TP and TN levels ( $\mathrm{p}=0.021$ and $\mathrm{p}=0.045$, respectively), with the ponds where feeding is more intense having showed the highest nutrient levels in their effluents. The results highlight the importance of mitigation measures such as educating the owners on proper water management, the installation of pond aerators in conjunction with tanks the filters of which shall be composed of aquatic macrophytes in their effluents, as well as awareness campaigns aiming to reduce the usage of dough by fishermen in order to minimize detrimental impacts on Guarapiranga's sub-basin.
\end{abstract}

Keywords: management, recreational fishing, environmental evaluation, nutrient load.

\section{Avaliação da qualidade da água de pesqueiros localizados na Sub-Bacia Guarapiranga, Alto Tietê, SP}

\section{Resumo}

Este estudo objetivou caracterizar, em termos estruturais e ambientais pesqueiros localizados na sub-bacia da Guarapiranga. A região de estudo foi mapeada, e do total de 24 pesque-pague georreferenciados, 15 foram entrevistados com os proprietários através de questionários semi-estruturados e, nos sete pesque-pagues com tributários mais próximos da represa, foram coletadas amostras de água em um ciclo sazonal divididas em quatro coletas entre novembro de 2013 a agosto de 2014. Foram medidos in situ: vazão, pH, turbidez, condutividade elétrica e oxigênio dissolvido nos afluentes e efluentes, e também foram coletadas amostras de água para determinação da concentração de fósforo total (PT) e nitrogênio total (NT). Os resultados mostraram que há uma diminuição nas concentrações de oxigênio dissolvido e aumento nas concentrações de PT e NT nos efluentes em relação aos afluentes. Os efluentes apresentaram valores de PT e NT acima dos limites permitidos pela resolução CONAMA 357/2005 - Classe II, ao menos em um período do ano. Também foram identificados afluentes com cargas elevadas de nutrientes, característica de bacias impactadas pelo adensamento populacional. Através do questionário aplicado aos proprietários sobre o manejo dos empreendimentos e pelas análises de água verificou-se que houve correlação significativa entre o arraçoamento diário e as cargas de PT e de NT ( $p=0,021$ e $p=0,045$, respectivamente), sendo que nos locais onde o arraçoamento foi mais intenso, a carga de 
nutrientes nos efluentes foi maior. Os resultados evidenciam a importância de medidas mitigadoras como orientações aos proprietários para o manejo adequado dos lagos, projetos de educação ambiental com os usuários para diminuir do uso de ceva para a captura dos peixes, além da instalação de aeradores artificiais nos lagos e tanques com filtros compostos de macrófitas aquáticas nos seus efluentes, minimizando os impactos na sub-bacia do Guarapiranga.

Palavras-chave: manejo, pesca recreativa, avaliação ambiental, carga de nutrientes.

\section{Introduction}

Guarapiranga reservoir is essential to 3.5 million people currently residing in the Metropolitan Region of São Paulo - MRSP who depend on its water supply. Over the last forty years, the reservoir was incorporated into the vast territory of the metropolis, and a population of almost one million people is currently estimated to be concentrated around its margins (Araújo and Solia, 2014).

Being it an urban reservoir, Guarapiranga suffers the impacts of several activities, such as public water supply, electricity generation, water sports, fishing, among others (Catunda, 2002).

Among the leisure options available around the reservoir, it is important to highlight the importance of fee-fishing ponds, which besides attending the fish trade system, offer leisure options in natural environments of MRSP. These environments require attention since its improper management may accelerate the process of artificial eutrophication (Matsuzaki et al., 2004).

Although the presence of fee-fishing ponds in rural and peri-urban regions may have positive effects on local economy, since it generates jobs and income as well as provides leisure, it can also cause negative environmental impacts as the water returning to the environment is generally of lower quality than the water initially used (Castro et al., 2006).

A fee-fishing pond is a commercial venture where recreational fishing can be performed in natural or artificial ponds, with farmed fish (Venturieri, 2002). Such ponds exploit fishing as a sports activity by holding a broad variety of species and thus acting as potential sources for dispersal of non-native species due to escapees adult individuals capable of colonizing their new environment. The escape of these individuals could represent a serious threat to the biodiversity of native species, modifying their habitat's natural conditions (Fernandes et al., 2003).

Besides clandestine sewage systems, industrial effluents, among others, the tributaries also receive effluents from fishing grounds, which may elevate the nutrients concentrations, especially phosphorus, in the sub-basins where they are located (Mercante et al., 2011).

Guarapiranga reservoir has been suffering with the fast and unplanned urban population growth in the region. It was classified as eutrophic to hypereutrophic in most months of 2013 and 2014 (CETESB, 2014, 2015). This is mainly due to high nutrient loads discharged into the reservoir by tributaries (Henry et al., 1999). Richter et al. (2007) found that the concentrations of ammonium and phosphate ions in some of the main tributaries of Guarapiranga reservoir were significantly higher than the ones observed in the main water body.
The purpose of the study was to identify, by interviews with the owners and water analysis, possible environmental impacts caused by fee-fishing on Guarapiranga reservoir, and to propose measures that can be used as subsidies for proper management of the activity, minimizing the impacts generated by its effluents.

\section{Material and Methods}

\subsection{Study area}

The basin of Guarapiranga reservoir is located in the southeastern part of the Metropolitan Region of São Paulo (234ㄱ'S; $\left.46^{\circ} 32^{\prime} \mathrm{W}\right)$, with a drainage area of $639 \mathrm{~km}^{2}$, it covers partially the municipalities of Cotia, Embu, Embu-Guaçu, Itapecerica da Serra, Juquitiba, São Lourenço da Serra, and São Paulo, as seen in Figure 1. Inserted in the area of Atlantic Forest, in 2003 there were only $37 \%$ of its original vegetation. Human uses account for $42 \%$ of the total basin area and include agriculture, mining, industries, recreation areas, housing, among other activities (Whately and Cunha, 2006a).

The reservoir has a flooded area of $33 \mathrm{~km}^{2}$, maximum depth of 13 meters and a theoretical retention time of 185 days. Its morphology is dendritic, narrow and elongated (CETESB, 2003; Whately and Cunha, 2006b). The main tributaries are Embu-Mirim, Embu-Guaçu, and Parelheiros rivers as well as several streams that provide an important contribution of nutrients to the reservoir, such as Guavirutuba and Itupu (Richter et al., 2007), as seen in Figure 1.

\subsection{Collection of data}

Data collection in the field was conducted through interviews with fee-fishing pond owners and collection of water samples, so that physical and chemical analysis could be performed in a laboratory. Among the 24 fee-fishing ponds identified, 15 allowed interviews with their respective owners, out of which only 7 gave us permission to take samples from the ponds effluents that flow into the reservoir (Figure 1).

\subsection{Interviews with the owners}

The owners or managers of the ponds were interviewed through specific structured and semi-structured questionnaires, developed by Boni and Quaresma (2005). They were asked about the fish species, their origins, the densities and dimensions of the ponds. As it was not possible to accurately identify the species, most fish were identified according to its popular names and through observation in situ, as well as photographic records. The interviews allowed obtaining the frequency of daily feeding the ponds in both periods (rainy and dry), as well as information on 
Sub-basian of Guarapiranga

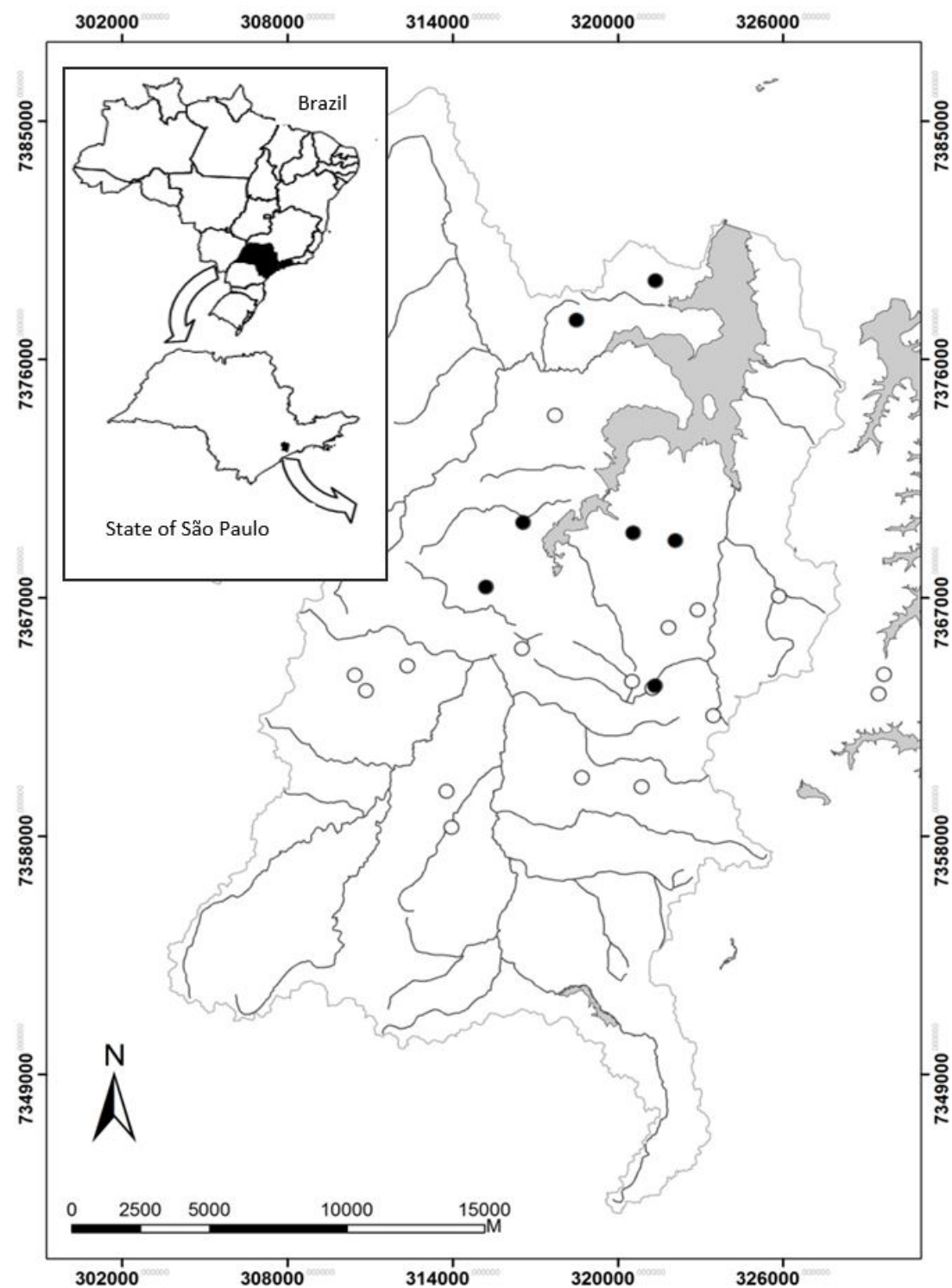

Figure 1. Guarapiranga reservoir sub-basin, with the location of fishing grounds in the region, from November 2013 to August 2014. Number of identified fishing grounds: 24(०); number of interviews conducted: 15; number of water samples collected: $7(\bullet)$.

the use of "dough fishing bait" and "other foods" by users in the four periods of the year. The amount was classified as "high" when most $(>50 \%)$ fishermen used dough and as "low" when $<50 \%$ made use of dough.

The questionnaires were submitted and approved by the Research and Ethics Committee/Municipal Health Department - CEP/SMS ( ${ }^{\circ}$ CAEE 42055215.2.0000.0086).

\subsection{Collecting water samples}

In order to assess the environmental impacts that fee-fishing can cause in water quality of Guarapiranga Reservoir, water samples were collected in seven fee-fishing ponds located closer to its margins, which could possibly generate a direct environmental impact in the reservoir. They were called: PP01, PP02, PP04, PP05, PP06, PP12, and PP15.

The affluents and effluents of each fee-fishing pond were sampled, being the main water input considered as affluent, and as effluents the water leaving the pond or the last pond when there were a set of ponds in the analyzed property. The field work was conducted between November 2013 and August 2014, and it was divided in four collections (November 2013, January 2014, April 2014, and August 2014), comprising the four seasons of the year. Parameters 
determined in situ: 1) Flow rates (L.s $\left.{ }^{-1}\right)$ by volumetric method, measuring the average time a certain water flow of water to fill a known volume container (Leopoldo and Souza, 1979), 2) Water temperature $\left.\left({ }^{\circ} \mathrm{C}\right), 3\right) \mathrm{pH}$, 4) Dissolved oxygen (mg. $\left.\left.\mathrm{L}^{-1}\right), 5\right)$ Turbidity (NTU) and 6) Electrical conductivity $\left(\mu \mathrm{S} . \mathrm{cm}^{-1}\right)$, using a multiparameter probe YSI model 6280. Surface water samples were collected, refrigerated and sent to SABESP's laboratory, where total nitrogen concentrations ( $\left.\mu \mathrm{g} . \mathrm{L}^{-1}\right)$ by Koroleff (1969)'s method and total phosphorus concentrations $\left(\mu \mathrm{g} . \mathrm{L}^{-1}\right)$, by the ascorbic acid method (APHA, 2005), were determined. The water samples were collected with the consent of the owners, who also received the analysis results on subsequent visits.

The difference between the nutrient loads of the affluents and effluents was estimated by the product of instant water flow rate $\left(\mathrm{L} . \mathrm{s}^{-1}\right)$ and TP and TN concentrations $\left(\mu \mathrm{g} . \mathrm{L}^{-1}\right)$ by means of the formula $\mathrm{L}=[\mathrm{N}] * \mathrm{Q}$, in which $\mathrm{L}=$ nutrients load; $[\mathrm{N}]=$ nutrient concentrations and $\mathrm{Q}=$ flow rate. The results were expressed in grams per day (g.day ${ }^{-1}$ ). The Trophic State Index (TSI) modified by Lamparelli (2004) of the affluents and effluents samples was calculated using the total phosphorus concentrations (TP) through the formula TSI $(\mathrm{TP})=10 *(6-((0,42-0,36 *(\operatorname{lnTP})) / \ln 2))-2$ (Lamparelli, 2004). These values means were compared with its referential to TP established by CONAMA Resolution 357/2005.

\subsection{Data analysis}

After the execution of the Shapiro-Wilk test, and comply with the assumptions of normality, a t test (one sample) was conducted to assess the differences between the results for total phosphorus and nitrogen of all effluent samples from the fee-fishing ponds, in relation to limit values, considering that the effluents are discharged into lotic environments that will flow to lentic environment (TP $=50 \mu \mathrm{g}$. $\mathrm{L}^{-1}$ and $\left.\mathrm{TN}=1270 \mu \mathrm{g} . \mathrm{L}^{-1}\right)$ of Class II of CONAMA Framework Resolution 357/2005 (CONAMA, 2005).

In order to describe the relationship between affluents and effluents from fee-fishing ponds and the abiotic variables, a Principal Component Analysis (PCA) was conducted using the correlation between the variables, run by PC-ORD software (McCune and Mefford, 2006).

In order to assess the effect from the average daily feed provision on the mean of $\mathrm{P}$ and $\mathrm{N}$ loads of effluents in both periods of the year (rainy and dry), it was used a simple regression analysis model and tested the correlation between the variables with Pearson coefficient (r) (Zar, 2010). In order to verify whether there was a significant difference in the use of dough by fishermen in the four periods of the year, a chi-square test was conducted (Zar, 2010).

\section{Results}

\subsection{Characterization of fee-fishing ponds in Guarapiranga's sub-basin through interviews with its owners}

According to the interviews with the owners, the fishing grounds were installed in Guarapiranga sub-basin during the 90 s and built in an average period of 3 years.
However, information on profits and required licenses for the operations were not provided.

The number of ponds varied greatly (from one to seven ponds). Most of the ventures have five ponds with an average depth of $2.26 \pm 0.88 \mathrm{~m}$. The shallowest depth was observed in PP06 (1.00 m) and the deepest one in PP17 and PP20 fishing grounds $(4.00 \mathrm{~m})$. Aerators are used in $40 \%$ of the fee-fishing ponds, $20 \%$ have settling ponds at the effluent output and $67 \%$ have containment filters or screens to avoid the fish from escaping.

The most frequent species of fish were: tilapia, mainly Oreochromis niloticus Linnaeus, 1758 and Coptodon rendalli Boulenger, 1897 (100\% occurrence), followed by pacu (Piaractus mesopotamicus Holmberg, 1887) (86.6\%), wolf fish (Hoplias malabaricus Bloch, 1794) (73.3\%), catfish (several species) (46.6\%), and carps (several species) (46.6\% occurrence). The fish supply comes mostly from fish farms located in the countryside of São Paulo, Paraná and Santa Catarina states, the stocking density was, during this study, $2.23 \pm 1.27 \mathrm{~kg}$ of fish per square meter.

In regards to feed provision performed by the owners of the 15 fee-fishing ponds, it was observed that $86 \%$ of them used their own feed for fish and $14 \%$ did not use it due to cost. The owners of PP12 and PP21 ponds stated that the fish meat tastes better when the dough they're fed is mixed with other grains.

\subsection{Analyses of physical and chemical water variables}

The results of physical and chemical variables of affluents and effluents from the studied fee-fishing ponds in the four periods of the year are shown in Figure 2. In some visits, (PP06, PP12 and PP15) it was not possible to carry out the measurement of the flow and the collection of water samples of affluents or effluents due to the maintenance of the ponds.

The flow rates of affluents and effluents had little variation among the fee-fishing ponds, the $f$ test (two samples) did not show significant difference $(\mathrm{p}=0.2652)$ exception for PP04 whose flow rates were much higher than the others. It was also possible to notice a subtle decrease in the flow rate of effluents in all sites.

The average water temperature ranged from 22 to $24^{\circ} \mathrm{C}$, being the highest values recorded in the effluents. The $\mathrm{pH}$ values varied greatly, with higher values also recorded in the effluents, except for PP04 and PP05, which presented higher values in its affluents. In all evaluated fee-fishing ponds, the concentration of dissolved oxygen was lower in the effluents than in the affluents, reaching values close to $1 \mathrm{mg} . \mathrm{L}^{-1}$ (PP12). In most of the fee-fishing ponds, the electrical conductivity was high both in the affluents and in the effluents $\left(>100 \mu \mathrm{S} . \mathrm{cm}^{-1}\right)$. It was also observed that in some places (PP02, PP04, and PP15) the values of these variables in the affluents were higher than those of effluents. The effluents of all fee-fishing ponds showed average values of higher turbidity values than the ones of effluents. PP12 and PP15 presented the highest average turbidity values. 

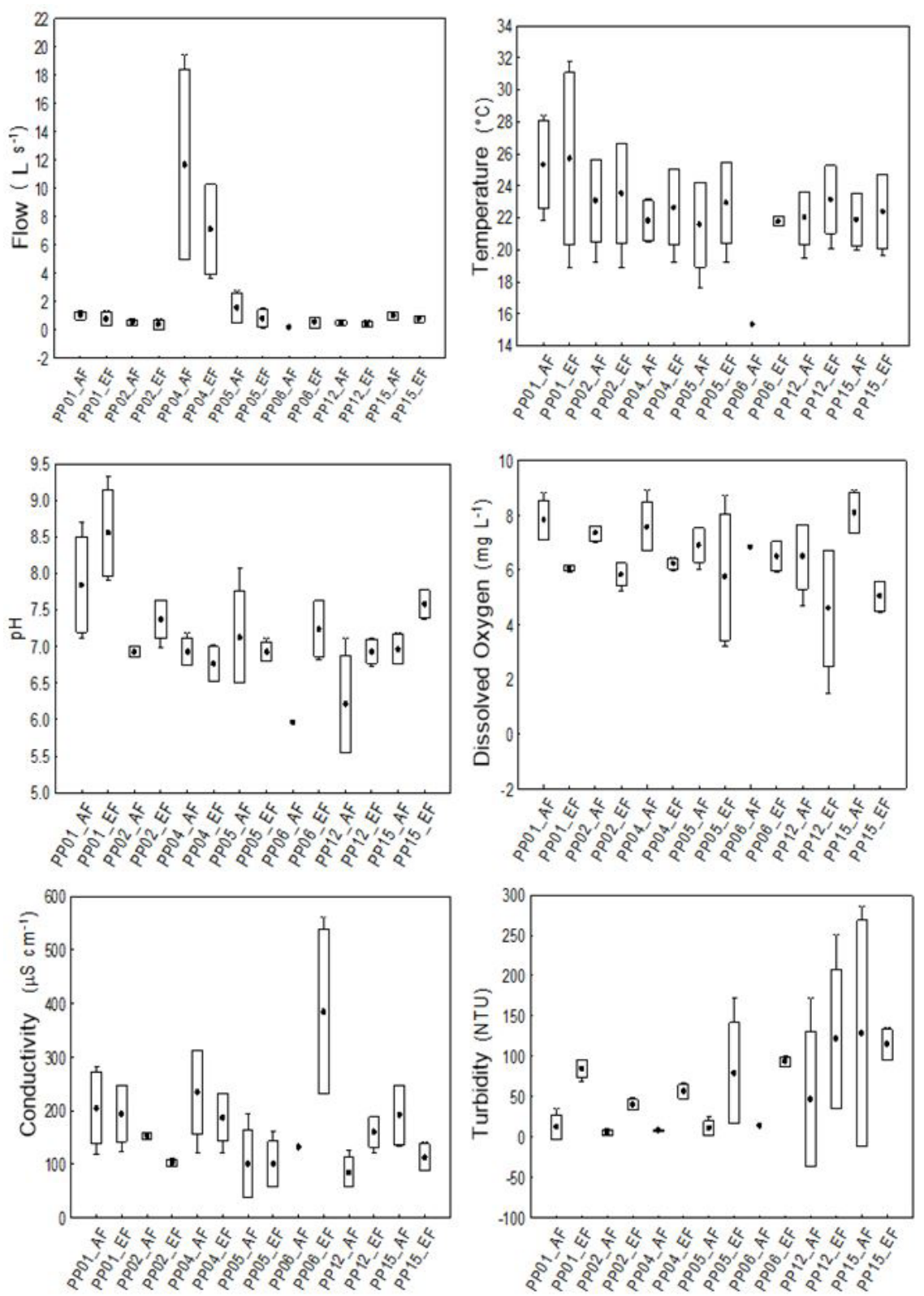

- Mean $\square$ Mean \pm SD I Min-Max

Figure 2. Average, standard deviation, and minimum and maximum values of physical and chemical variables of affluents and effluents of fee-fishing ponds in Guarapiranga's sub-basin (SP), between November 2013 and October 2014.

Concerning the concentrations of total phosphorus and nitrogen (Figure 3), the concentrations of both nutrients were higher in the effluents than in the affluents. When compared with the limit of CONAMA 357/2005 for effluents lotic waters (50 $\mu \mathrm{g} . \mathrm{L}^{-1}$ and $1270 \mu \mathrm{g} . \mathrm{L}^{-1}$, respectively) the concentrations of total phosphorus $(\mathrm{P})$ and total nitrogen $(\mathrm{N})$ of the effluents, were significantly different $(\mathrm{p}<0.001)$.

All fee-fishing ponds had, at some point, concentrations of $\mathrm{P}$ and $\mathrm{N}$ in effluents higher than the limit established by CONAMA Directive 357/2005 - Class II. It is important to note that the concentration of these nutrients in the affluents, especially total nitrogen, was also high in most fee-fishing ponds analyzed.

The Principal Component Analysis (PCA) that was conducted based on physical and chemical water parameters allowed accounting for $93.9 \%$ of the data variation, where component 1 accounted for $77.9 \%$ and component 2 accounted for $16 \%$. The first component of this analysis clearly showed the separation between effluents and affluents in the studied fee-fishing ponds, 
showing that the effluents are characterized by higher turbidity and higher concentrations of TP and TN, whereas the affluents have higher dissolved oxygen concentrations (Figure 4).

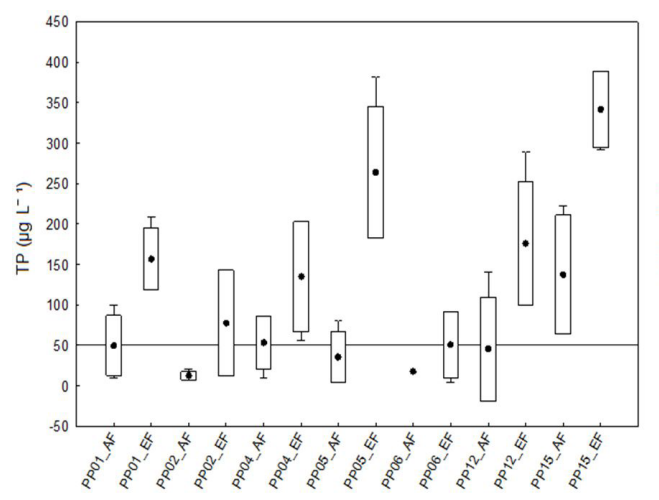

Figure 5 illustrates the balance of TP and TN load generated in the fishing ponds, considering the TP and TN load discharge in the effluents versus the TP and TN load intake in the affluents.

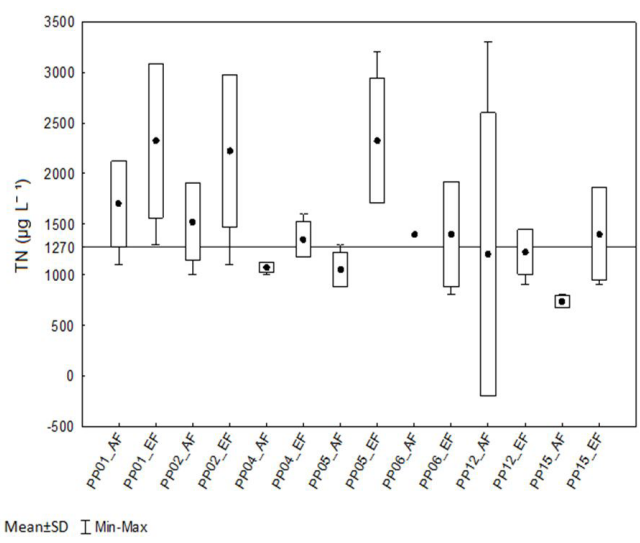

Figure 3. Average, standard deviation, and minimum and maximum values of total nitrogen (TN) and total phosphorus (TP) concentrations in affluents and effluents of fee-fishing ponds in Guarapiranga's sub-basin (SP), between November 2013 and October 2014. (A indicates the limit as per CONAMA Resolution no. 357/2005 - Class II for total nitrogen $\left(1270 \mu \mathrm{g} \mathrm{L}^{-1}\right)$ and total phosphorus $\left(50 \mu \mathrm{g} \mathrm{L}^{-1}\right)$.

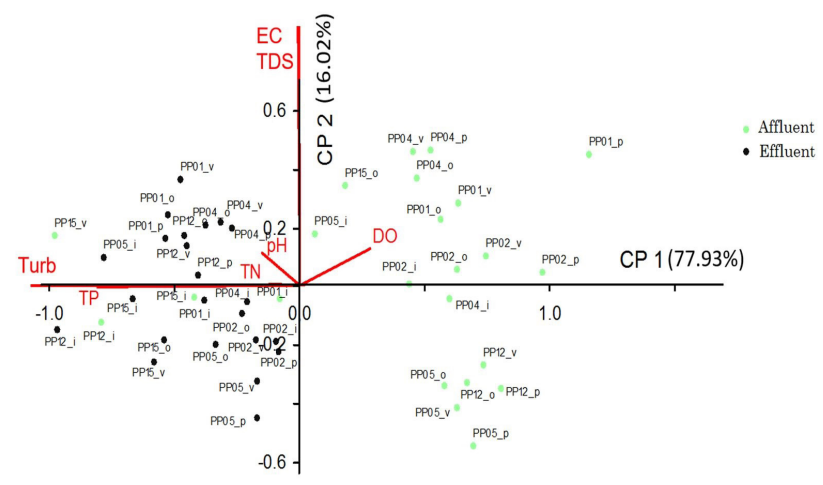

Figure 4. Biplot associated with the Principal Component Analysis (PCA) for physical and chemical variables of affluents and effluents of fee-fishing ponds in Guarapiranga's sub-basin between November 2013 and October 2014. (p: spring; v: summer; o: fall; i: winter; TN: total nitrogen; TP: total phosphorus; DO: dissolved oxygen; Turb: turbidity; EC: electrical conductivity; TDS: total dissolved solids; $\mathrm{pH}$ : $\mathrm{pH}$; $\mathrm{CP} 1$ : principal component 1; $\mathrm{CP} 2$ : principal compenent 2.
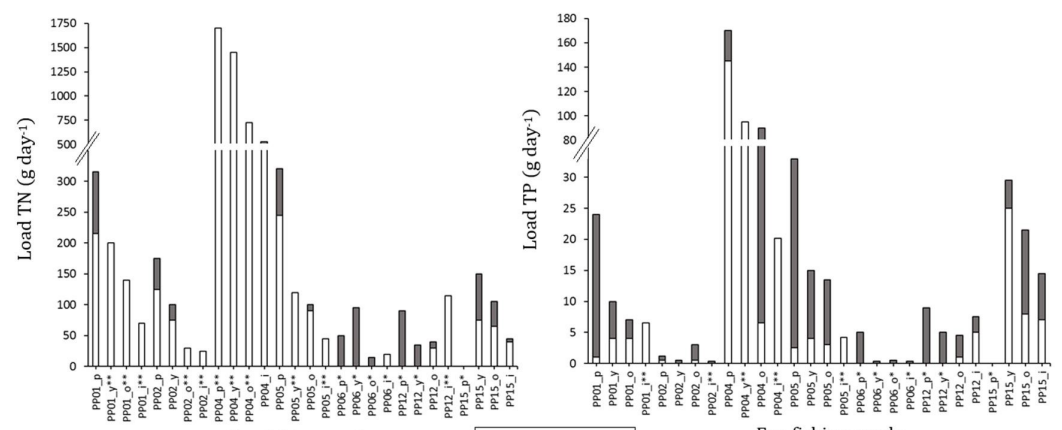

口Affluent aEffluent Fee-fishing ponds

Figure 5. Total level of nutrients exported by the effluents of fee-fishing ponds in Guarapiranga's sub-basin, as compared to the one in the affluent fractions. (TN: total nitrogen; TP: total phosphorus; p: spring; y: summer; o: fall; i: winter; between November 2013 and August 2014. (*indicates a place where no affluents or effluents were sampled, **indicates a place where the nutrient levels of affluents exceeded the ones in effluents). 


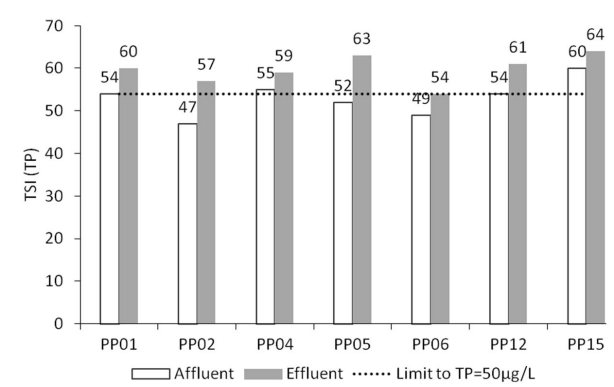

Figure 6. Trophic state index of total phosphorus (TSI-TP) in affluents and effluents of the fee-fishing ponds in Guarapiranga's sub-basin, during the monitored period. $\mathrm{TSI}=54$ corresponds to TSI calculated for $50 \mu \mathrm{g} \mathrm{L}^{-1} \mathrm{TP}$ (corresponding to the limit as per CONAMA). Weighting: TST $\leq 47=$ ultra-oligotrophic; $47<\mathrm{TSI} \leq 52=$ oligotrophic; $52<$ TSI $\leq 59=$ mesotrophic; $59<$ TSI $\leq 63=$ =utrophic; $63<$ TSI $\leq 67=$ super-eutrophic; TSI $>67=$ hyper-eutrophic).

Table 1. Information on feed provision in the fee-fishing ponds in Guarapiranga's sub-basin, which was obtained through interviews indicating the average quantity of feed $\left(\right.$ g.day $\left.^{-1}\right)$ used in the management of the ponds between November 2013 and August 2014.

\begin{tabular}{|c|c|c|}
\hline \multirow{2}{*}{$\begin{array}{c}\text { Fee-fishing } \\
\text { pond }\end{array}$} & \multicolumn{2}{|c|}{ Period of the year } \\
\hline & Rainy (g.day ${ }^{-1}$ ) & Dry (g.day $\left.{ }^{-1}\right)$ \\
\hline PP01 & 1000 & 143 \\
\hline PP02 & 200 & 0 \\
\hline PP04 & 0 & 0 \\
\hline PP05 & 500 & 71 \\
\hline PP06 & 500 & 71 \\
\hline PP08 & 500 & 71 \\
\hline PP09 & 17 & 17 \\
\hline PP10 & 333 & 333 \\
\hline PP12 & 500 & 71 \\
\hline PP15 & 1000 & 143 \\
\hline PP17 & 1000 & 143 \\
\hline PP20 & 1500 & 33 \\
\hline
\end{tabular}

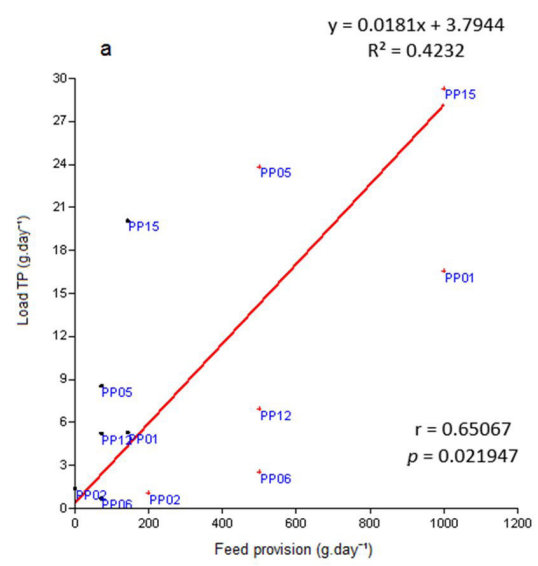

Most fee-fishing ponds showed an increase of phosphorus loads in its effluent. However, in some sites, such as PP01 in winter, PP04 in summer and winter, and PP05 in winter, the highest load was already present in the affluent, occurring reversal, with lower total phosphorus level in the effluent. Despite the total nitrogen value being very high in the effluents of studied fee-fishing ponds, most places - PP01, PP02, PP04, PP05, and PP12 - had its highest levels already present in the affluents, and as well as for total phosphorus, also noting a reduction of their levels in the effluents.

The trophic state index (TSI) of affluents and effluents of the fee-fishing ponds is presented in Figure 6. During the monitored period, most of the affluents of the fee-fishing ponds were classified as mesotrophic $(52<\mathrm{TSI} \leq 59)$, fee-fishing ponds PP05 and PP06 were the only ones classified as oligotrophic $(47<\mathrm{TSI} \leq 52)$, and PP02 showed the best condition, being classified as ultra-oligotrophic (TSI $\leq 47$ ). On the other hand, all effluents analyzed presented higher values than what would be recommended, the limit values considered in this calculation being the TP index set by CONAMA 357/2005 (TSI = 54), with highlights to PP01, PP05, and PP12, which were found as eutrophic $(59<\mathrm{TSI} \leq 63)$; and PP15 as super-eutrophic $(63<\mathrm{TSI} \leq 67)$.

\subsection{Analyses of feed provision management}

Table 1 shows the results of the owners on daily feed provision during the rainy and dry season in the fee-fishing ponds. The results of simple linear regression analysis between daily feed provision and phosphorus and nitrogen levels in the fee-fishing pond effluents in both periods (rainy and dry) are shown in Figure 7. Six ventures provided information on average daily feed provision and allowed samples to be collected for the water analysis. Pearson correlation coefficient was significant $(\mathrm{p}=0.021$, and $\mathrm{p}=0.045)$, and correlation values indicate moderate correlation ( $\mathrm{r}=0.65067$ and $\mathrm{r}=0.58451$, respectively).

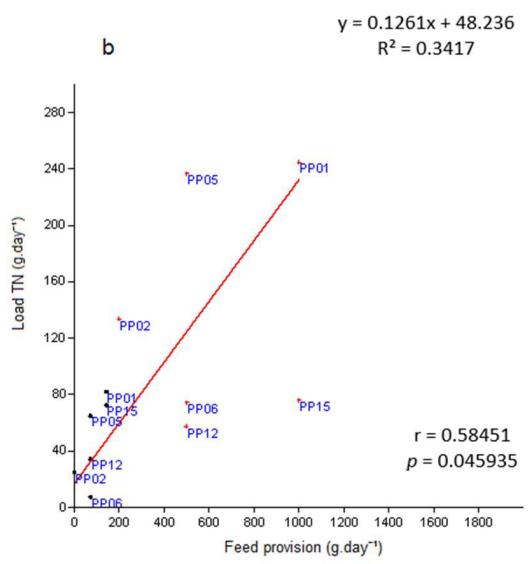

Figure 7. Relationship between the total phosphorus level (a) and the total nitrogen level (b) in the effluents of the fee-fishing ponds in Guarapiranga's sub-basin and the daily feed provision in the ponds that was conducted by their owners in the rainy $(+$ red) and dry periods $(\bullet)$ (from November 2013 to August 2014). *PP04 there was no value regarding feed provision over the period. 
Table 2. Percentages of owners' perceptions regarding the amount of grains used by fishermen in the fee-fishing ponds in Guarapiranga's sub-basin, between November 2013 and August 2014.

\begin{tabular}{ccccc}
\hline Observed & \multicolumn{4}{c}{ Season } \\
\cline { 2 - 5 } amount & Spring & Summer & Fall & Winter \\
\hline Much & $47 \%$ & $40 \%$ & $67 \%$ & $80 \%$ \\
Little & $53 \%$ & $60 \%$ & $33 \%$ & $20 \%$ \\
\hline
\end{tabular}

Note: Much $=$ over $50 \%$ of the fishermen used some kind of grain.

\subsection{Analysis of the owners' perceptions regarding the use of dough fishing bait by users}

Considering the 15 fee-fishing pounds evaluated, no significant difference was found (chi-squared test $=6.24$; $\mathrm{p}=0.1005$ ) in the four periods of the year regarding the use of "doughs" or "other foods" by the fishermen to capture fish in the fee-fishing ponds. Through this test, it was found that regardless of the season, the users make use of similar amounts of dough (Table 2).

\section{Discussion}

The fee-fishing ponds in the sub-basin of Guarapiranga analyzed in the present study were built in the 1990s, corroborating the study by Kitamura et al. (1999), which showed that the fee-fishing pond sector greatly developed in São Paulo state throughout this period.

Information on profits and operating licenses of ventures were difficult to obtain. However, the fee-fishing ponds in the sub-basin were observed to generate revenue from services such as restaurants, bars and entrance fees, as well as from charging fishermen for the weight of fish captured by them in kilograms, which is a common practice among fee-fishing pond systems (Oliveira and Fukushima, 1998; Kitamura et al., 1999). In regards to the licenses, Esteves and Ishikawa (2006) observed that in the region of Guarapiranga, most fishing grounds did not have all permits required to operate.

The average number of ponds found in the fee-fishing ponds of the sub-basin was three, ranging from 1 to 7 . The values were similar to the ones found for Piracicaba river (Kitamura et al., 1999). The number of ponds enables owners to offer different fish species to clients.

This study showed that the higher the water volume in a venture, the larger is the stocking of fish. Only one fee-fishing pond was found to not having this characteristic, as its fishing activities were suspended. The average biomass storage in the studied sites is $2.23 \mathrm{~kg} \mathrm{~m}^{-2}$, which is five times the ideal limit (Sanches and Graça-Lopes, 2006), and it certainly contributes to increase pollution load in effluents.

Although the owners have said in the interviews that they are worried about fish escaping, 33\% of them said they didn't have any kind of physical screens or barriers in the effluents of their fee-fishing ponds. As the predominant species in the studied fishing grounds are not native, their escapes from fee-fishing ponds directly in the tributaries of the reservoir is a potential risk to the balance of the native aquatic fauna, showing the importance of fishing grounds as potential sources for dispersion of allochthonous species (Fernandes et al., 2003; Castellani and Barrella, 2005).

The highest occurrence of non-native species in the ventures is due to its great acceptance and its good monetary return. A recent study on the ichthyofauna of Guarapiranga Reservoir found the presence of species from other basins in this reservoir (Maruyama et al., 2014). Therefore, an awareness work with the owners and users of these enterprises could contribute to proper management to prevent the escape of these species.

This study showed that improper management of ponds may contribute to worsen water quality and that the concentration of nutrients in the effluent increased considerably, as compared to its affluents, in fishing grounds where the feed provision is more intense. Besides that, the fee-fishing pond that did not use its own feed for fish (PP12) had the lowest concentration of dissolved oxygen in its effluents. On the other hand, the owner of PP04 reported not feeding the fish because "the fish live on what there is in the ponds". In fact, the load of nutrients in this place was very high, and three out of four periods of the year analyzed there was a reduction of these nutrients in the effluents.

Although this research has been conducted among the most severe drought periods and the driest rainy season in 19 years, differences were observed between the rainy and dry periods (CETESB, 2015). That is clear when a reduction to almost half of the flow rates measured in affluent and effluent of fee-fishing ponds analyzed in the dry period. As it is a determining factor for obtaining the values of polluting loads, differences were found among year periods.

Most physical and chemical variables analyzed did not comply with the values allowed by legislation. It was observed that $\mathrm{pH}$ was higher in effluents where feeding was realized, particularly in PP01, with values above the limits recommended by CONAMA Resolution 357/2005 (between 6.0 and 9.0) in some periods. That may happen when unused food remains in the environment, which enables phytoplankton to grow, especially cyanobacteria, enhancing the photosynthetic process that ends up raising the $\mathrm{pH}$ in ponds (Sipaúba-Tavares et al., 1995; Esteves, 1998; Kubitza 1998).

Water oxygenation is an important factor for fee-fishing ponds, but during the monitored period, all analyzed fee-fishing ponds had reductions in values of dissolved oxygen in their effluents, indicating improper water circulation in the ponds. During the visits, $60 \%$ of the ventures were observed not to have aerators. Artificial aeration systems and/or water recirculation systems with the use of watermills or windmills, in order to save electricity, bring benefits to fee-fishing ponds (Queiroz et al., 2002). If activated few hours before sunrise, when ponds reach critical levels of dissolved oxygen, and deactivated a few hours after sunrise, it may improve oxygenation in 
the ponds and facilitate the dispersion of unused feeding (Kubitza, 1998).

In most effluents from fee-fishing ponds, focus of this research, the electrical conductivity values were very high, which indicates a high concentration of ions in the water, coming probably from high decomposition rates (Esteves, 1998). However, it was noticed that the electrical conductivity of the affluents was already high and, in many places, such values diminished in the effluents. This is because although the studied region is a spring area, it suffers from unplanned population growth and untreated household effluents. Thus, although the improper feed provision and use of dough increases the presence of decomposing material, changes in electrical conductivity will depend mainly on the characteristics of the water upstream from the ponds, a fact that was also observed by Millan (2009). This means that under specific circumstances the fee fishing ponds are nutrient sinks and not sources.

In general, the turbidity and electrical conductivity values exceeded the recommended values ( $100 \mathrm{NTU})$ during the monitored period. High turbidity is also caused by the high density of phytoplankton, which has a fast growth rate in high temperature environments, with good light conditions and high concentration of nutrients, such as the ones provided by fishing grounds (Sipaúba-Tavares et al., 2011).

A difference was observed between periods of the year, in regards to the concentration of nutrients, with higher values during the rainy period (summer and spring). The values of total phosphorus were very high in the effluents, above the limits from CONAMA Resolution 357/2005 - Class II, similar to the ones obtained in a study by Mercante et al. (2011) on fishing grounds in the metropolitan region of São Paulo. The phosphorus coming from feeds and dough fishing bait (Esteves, 1998). The concentration of nitrogen was also high in the affluents, rising during the rainy period. However, it is important to observe that there are still sites in the sub-basin with unaffected springs, because although most of the affluents were classified as mesotrophic, two of them were classified as oligotrophic and one as ultra-oligotrophic. On the other hand, all effluents were classified as eutrophic and one of them as super-eutrophic, demonstrating that the total phosphorus values exceeded the limits recommended by CONAMA Resolution 357/2005. According to Lamparelli (2004) the importance of evaluating phosphorus in most aquatic environments is undeniable, once this nutrient limits the trophic process and is one of the most important factors in the system regulation.

Controlling the flow of the fee-fishing ponds effluents is an important factor in reducing the impacts generated. Even though the ventures presented concentrations of total phosphorus and nitrogen above CONAMA limit, the reduction of effluent flow contributes to the lower levels in some of them. The lower the flow of an effluent, the lower the load of nutrients exported.

Treating the effluents of these ventures is essential to reduce the impacts that may be caused to the basins where they are located. Settling ponds may contribute greatly to the treatment process. According to Henry-Silva and Camargo (2008), effluent treatment systems by macrophytes may be viable for processes originated from aquaculture, and they minimize the impacts on aquatic ecosystems located downstream of these ventures.

Henry-Silva and Camargo (2006) proved the effective ability of the floating aquatic macrophytes (Eichhornia crassipes and Pistia stratiotes) to remove particulate organic matter and nutrients from their effluents, reaching values close to $70 \%$ for total phosphorus removal.

The management measures to improve effluents are, in many cases, simple and easy to be installed. According to Hussar and Bastos (2008), the performance of lagoons with floating aquatic macrophytes is satisfactory and efficient in the removal of nutrients, and building and managing them is inexpensive. It is common to see in the floodplains of Guarapiranga reservoir the presence of water tanks with volumetric capacity able to support the flow of the venture, equipped with buoys, which maintain constant level of the tanks, where floating aquatic macrophytes can be grown (e.g., E. crassipes).

Considering that the water from the fee-fishing ponds may influence the water quality of Guarapiranga reservoir, all owners interviewed understood the possible negative impact of their activities, once they also use water from the public supply system in their homes, if not in their fee-fishing ponds.

Instruction booklets can be prepared and distributed to owners to guide better management of ponds through feed provision, the restriction in the use of dough by fishermen, through using aeration systems and installation of filters with aquatic plants in the ponds, which together may serve as models in order to minimize the impacts of the fee-fishing pond in the region.

\section{Conclusion}

Interviewing the owners of fishing grounds through questionnaires coupled with the collection of water from effluents and affluents of fee-fishing ponds have both shown to be tools of great importance in collecting and analyzing information on the management and characterization of ventures installed at sub-basin of Guarapiranga.

An awareness work with the owners and users of these ventures could contribute to appropriate management in relation to feed provision, the storage of biomass, the use of dough by fishermen and the escape of exotic species with invasive potential of water bodies downstream from these ventures. Such management actions could, in the short run, contribute to promoting a sustainable activity to preserve the basin of Guarapiranga.

\section{References}

AMERICAN PUBLIC HEALTH ASSOCIATION - APHA, AMERICAN WATER WORKS ASSOCIATION - AWWA and WATER ENVIRONMENT FEDERATION - WEF, 2005. 4500-P 
E-ascorbic acid method: standard methods for the examination of water and wastewater. 21 st ed. Washington: APHA.

ARAÚJO, R. and SOLIA, M., 2014. Guarapiranga 100 anos. São Paulo: Fundação Energia e Saneamento. 199 p.

BONI, V. and QUARESMA, S.J., 2005. Aprendendo a entrevistar: como fazer entrevistas em Ciências Sociais. Tese, vol. 2, no. 1, pp. $68-80$.

CASTELLANI, D. and BARRELLA, W., 2005. Caracterização da piscicultura na região do Vale do Ribeira-SP. Ciência e Agrotecnologia, vol. 29, no. 1, pp. 168-176. http://dx.doi. org/10.1590/S1413-70542005000100021.

CASTRO, P.M.G., MARUYAMA, L.S., MENEZES, L.C.B. and MERCANTE, C.T.J., 2006. Perspectivas da atividade de pesqueiros no Alto Tietê: Contribuição à gestão de usos múltiplos da água. Boletim do Instituto de Pesca, vol. 32, no. 1, pp. 1-14.

CATUNDA, C.N.G., 2002. Conflitos da expansão urbana na bacia hidrográfica de Guarapiranga: a ocupação urbana e o papel desempenhado pelos instrumentos de planejamento urbano ambiental na configuração do espaço. In: R. ABRAMOVAY, org. Construindo a ciência ambiental. São Paulo: Annablume, pp. $75-113$

COMPANHIA AMBIENTAL DO ESTADO DE SÃO PAULO CETESB, 2003. Qualidade das águas superficiais no estado de São Paulo 2002. São Paulo: CETESB, 279 p. Série Relatórios.

COMPANHIAAMBIENTAL DO ESTADO DE SÃO PAULO CETESB, 2014. Qualidade das águas superficiais no estado de São Paulo 2013. São Paulo: CETESB, 434 p. Série Relatórios.

COMPANHIA AMBIENTAL DO ESTADO DE SÃO PAULO CETESB, 2015. Qualidade das águas superficiais no estado de São Paulo 2014. São Paulo: CETESB, 520 p. Série Relatórios.

CONSELHO NACIONAL DO MEIO AMBIENTE - CONAMA, 2005. Resolução $n^{\circ}$ 357, de 17 de Março de 2005. Dispõe sobre a classificação dos corpos de água e diretrizes ambientais para o seu enquadramento, bem como estabelece as condições $e$ padrões de lançamento de efluentes, e dá outras providências. Diário Oficial da União, Brasília, 18 de março, no. 53, pp. 58.

ESTEVES, F.A., 1998. Fundamentos de Limnologia. 2. ed. Rio de Janeiro: Interciência, 602 p.

ESTEVES, K.E. and ISHIKAWA, C.M., 2006 Características gerais e práticas de manejo em pesqueiros da região metropolitana de São Paulo. In: K. E. ESTEVES, C. L. SANT'ANNA. Pesqueiros sob uma Visão Integrada de Meio Ambiente, Saúde Pública e Manejo. Um Estudo da Região Metropolitana de São Paulo. São Carlos: RiMa, pp. 1-17.

FERNANDES, R., GOMES, L.C. and AGOSTINHO, A.A., 2003. Pesque-pague: negócio ou fonte de dispersão de espécies exóticas? Acta Scientiarum, vol. 25, no. 1, pp. 115-120. http:// dx.doi.org/10.4025/actascibiolsci.v25i1.2089.

HENRY, R., SANTOS, A.A.N. and CAMARGO, Y.R., 1999. Transporte de sólidos suspensos, N e P total pelos Rios Paranapanema e Taquari e uma avaliação de sua exportação na represa Jurumirim (São Paulo, Brasil). In: R. HENRY. Ecologia de reservatórios: estrutura, função e aspectos sociais. Botucatu: Fapesp/FUNDIBIO, pp. 689-710.

HENRY-SILVA, G.G. and CAMARGO, A.F.M., 2006. Efficiency of aquatic macrophytes to treat Nile tilapia pond effluents. Scientia Agrícola, vol. 63, no. 5, pp. 433-438. http://dx.doi.org/10.1590/ S0103-90162006000500003.
HENRY-SILVA, G.G. and CAMARGO, A.F.M., 2008. Tratamento de efluentes de carcinicultura por macrófitas aquáticas flutuantes. Revista Brasileira de Zootecnia, vol. 37, no. 2, pp. 181-188. http:// dx.doi.org/10.1590/S1516-35982008000200002.

HUSSAR, G.J. and BASTOS, M.C., 2008. Tratamento de efluente de piscicultura com macrófitas aquáticas flutuantes. Engenharia Ambiental, vol. 5, no. 3, pp. 274-285.

KITAMURA, P.C., LOPES, R.B., CASTRO-JUNIOR, F.G. and QUEIROZ, J.F., 1999. Avaliação ambiental e econômica dos lagos de pesca esportiva na bacia do Rio Piracicaba. Boletim de Indústria Animal, vol. 56, no. 1, pp. 95-107.

KOROLEFF, F., 1969. Determination of total nitrogen in natural Waters by means of persulfate oxidation. Copenhagen: International Council for the Exploration of the Sea - ICES. Pap. C.M. 1969/C:8 Revised.

KUBITZA, F., 1998. Qualidade da água na produção de peixes - Parte II. Panorama da Aquicultura, vol. 8, no. 46, pp. 35-41.

LAMPARELLI, M.C., 2004 [viewed 15 July 2014]. Grau de trofia em corpos d'água do estado de São Paulo: avaliação dos métodos de monitoramento [online]. São Paulo: Instituto de Biociências, Universidade de São Paulo, 235 p. Tese de Doutorado. Available from: http://www.teses.usp.br

LEOPOLDO, P.R. and SOUZA, A.P., 1979. Hidrometria. Botucatu: Departamento de Engenharia Rural, Universidade Estadual Paulista. 9 p.

MARUYAMA, L.S., ESPÍNDOLA, E.L.G., PEREIRA, L.P.F., BUENO, A.S., ALMEIDA, I.M.T. and CASTRO, P.M., 2014. Ichthyofauna in Guarapiranga dam (São Paulo, Brazil), as a resource of funds for recreational and professional fishing. In: Proceedings of the 7th World Recreational Fishing Conference, 2014, Campinas. Campinas. pp. 48-49.

MATSUZAKI, M., MUCCI, J.L.N. and ROCHA, A.A., 2004. Comunidade fitoplanctônica de um pesqueiro na cidade de São Paulo. Revista de Saude Publica, vol. 38, no. 5, pp. 679-686. http:// dx.doi.org/10.1590/S0034-89102004000500010. PMid:15499439.

MCCUNE, B. and MEFFORD, M.J., 2006. PC-ORD: multivariate analysis of ecological data. Version 5.31. Gleneden Beach: MjM Software.

MERCANTE, C.T.J., PEREIRA, J.S., MARUYAMA, L.S., CASTRO, P.M.G., MENEZES, L.C.B., SENDACZ, S. and DI GENARO, A.C., 2011. Qualidade da água de efluentes de pesqueiros situados na bacia do Alto Tietê. Bioikos (Campinas), vol. 25 , no. 1 , pp. $45-52$.

MILlAN, R.N., 2009 [viewed 04 May 2015]. Dinâmica da qualidade da água em tanques de peixes de sistema pesque-pague: aspectos fisico-químicos e plâncton [online]. Jaboticabal: Centro de Aquicultura, Universidade Estadual Paulista, 88 p. Dissertação de Mestrado. Available from: http://www.caunesp.unesp.br/pg/ trabalhos_dissertacoes_autor.php

OLIVEIRA, L.H. and FUKUSHIMA, S.E., 1998. Sistema integrado de gestão: o caso dos pesqueiros na região da Grande São Paulo. Revista da Universidade de Alfenas, vol. 4, pp. 217-224.

QUEIROZ, J.F., LOURENÇO, J.N.P. and KITAMURA, P.C., 2002. A Embrapa e a aqüicultura: demandas e prioridades de pesquisa. Brasília: Embrapa, 35 p.

RICHTER, E.M., FORNARO, A., LAGO, C.L. and ANGNES, L., 2007. Avaliação da composição química de águas do Sistema 
Guarapiranga: estudo de caso nos anos de 2002 e 2003. Quimica Nova, vol. 30, no. 5, pp. 1147-1152. http://dx.doi.org/10.1590/ S0100-40422007000500018.

SANCHES, E.G. and GRAÇA-LOPES, R., 2006. Avaliação da dinâmica de movimentação de peixes em um estabelecimento de pesca esportiva tipo "pesque e solte". Revista Brasileira de Saúde e Produção Animal, vol. 7, no. 1, pp. 38-46.

SIPAÚBA-TAVARES, L.H., DONADON, A.R.V. and MILAN, R.N., 2011. Water quality and plankton populations in an earthern polyculture pond. Brazilian Journal of Biology $=$ Revista Brasileira de Biologia, vol. 71, no. 4, pp. 845-855. http://dx.doi.org/10.1590/ S1519-69842011000500005.

SIPAÚBA-TAVARES, L.H., LIGEIRO, S.R. and DURIGAN, J.G., 1995. Variação de alguns parâmetros limnológicos em um viveiro de piscicultura em função da luz. Acta Limnologica Brasiliensia, vol. 7, pp. 138-150.

VENTURIERI, R., 2002. Pesque-pague no Estado de São Paulo. São Paulo: Eco-Associação para Estudos do Ambiente. 168 p.

WHATELY, M. and CUNHA, P., 2006a. Seminário Guarapiranga: proposição de ações prioritárias para garantir água de boa qualidade para abastecimento público. São Paulo: Instituto Socioambiental, $171 \mathrm{p}$.

WHATELY, M. and CUNHA, P., 2006b. Guarapiranga 2005: como e por que São Paulo está perdendo este manancial. Resultado do Diagnóstico Socioambiental participativo da bacia Hidrográfica da Guarapiranga. São Paulo: Instituto Socioambiental. 48 p.

ZAR, J.H. 2010. Biostatistical analysis. 5. ed. New Jersey: Pearson Prentice Hall, 944 p. 